\title{
Does Damage from Natural Disaster Affect Child Labor? Evidence from Indonesia
}

\author{
Tito Sulistyo ${ }^{\mathrm{a}, *}$, \& Wildan Syafitri ${ }^{\mathrm{a}}$ \\ ${ }^{a}$ Department of Economics, Faculty of Economics and Business, University of Brawijaya, Malang
}

\begin{abstract}
Disasters, both natural and non-natural, can cause a severe impact on every life aspects in a country, including the economic aspect. In Indonesia, as a reaction of deteriorating economic conditions caused by disasters, households are often forced to adjust the declining of their real income by taking out their children from school thereby they can send them to work as a household buffer to shocks. This paper aims to analyze the impact of the natural disaster damage on the number of child labor and the differences of these impacts between urban and rural areas. By using cross section data from the fifth wave Indonesia Family Life Survey collected in 2014, we find that there is a positive relation between the natural disaster damage and the number of child labor, and then a significant difference between impacts in urban and rural areas. Policy implications of the findings are provided.
\end{abstract}

Keywords: child labor; natural disaster; disaster damage; urban; rural JEL Classification: J29; I22; R1

\footnotetext{
${ }^{*}$ Corresponding Address: Departemen Ilmu Ekonomi, FEB Universitas Brawijaya, Jln. MT. Haryono No. 165, Ketawanggede, Kec. Lowokwaru, Kota Malang, Jawa Timur 65300. E-mail: titosulistyo@student.ub.ac.id.
} 


\section{Introduction}

The main cause of the high rate of child labor in developing countries is a crucial problem for policy makers. It is imperative for both nation and parents to ensure that every child has the best opportunity for healthy development, access to quality education, and future productivity. It is also mandatory for both nation and parents to ensure that they are well prepared for any situation that is dangerous to children and detrimental to them. In short, making every effort possible to guarantee the satisfaction of the children's human rights is a duty for all parties.

According to the data in the world these days, around 218 million children are working. A more detailed that 152 million of child labor are caused by coercive action; almost half of them, around 73 million are engage in dangerous circumstances such as in hazardous environments, become a slave or other types of forced labor, doing an illegal jobs including drug trafficking and prostitution, and involvement in armed conflict.

Many empirical studies of the factors which determine the involvement of the child in work show that economic and social factors are the key factor as a driver of child involvement in the labor market. Basu \& Van (1998) and Ray (2000) note that economic factors such as household income influence parents and children's decisions to involve children in work. Edmonds (2006) found that social factors such as low rates of parent education influence the participation of children in work. In their research, Tang et al. (2016) found that the number of adults and household-owned assets was not allowing their children to become a worker yet. Whereas the (rural) residential status is tend to allow or even to force their children to participate in household livelihood responsibilities. However, both children and parents gender as well as parents' education do not affect child labor participation.

Households also face numerous high-risk issues that cause low investment in human resources, such as the economic downturn, death of the head or family member, sickness, crop failure or loss of income triggered by natural weather phenomena, insect attacks and so on (Maccini \& Yang, 2009). This phenomenon has indirect implications for high income fluctuations and enforcing their child to become a labor is often a household decision to deal with it. Turning their child's school days into a working days as a household buffer shock is one of the last strategies or mechanisms to perform consumption smoothing mostly in developing countries, especially rural areas (Beegle et al., 2006). Skoufias \& Parker (2002) notes that the child labor phenomenon is closely related to the poor capacity of households, both in formal and informal institutions, to survive from various shocks. Therefore, the household that being hopeless for aid or protection chance would be encouraged to use all the human resources they have, including children, to work or earn income. Regardless of disparities in the economic circumstances underlying those decisions, the use of child labor as a household buffer shock cannot be excluded. What occurs most crucially 
is that there is a disparity between economic actors in the amount of income. Some developing countries not only have low income rates, but also high risk characteristics and low possibility of diversifying the risk due to the current poor insurance market, and face liquidity constraints. Fitzsimons (2007) shows that one of the reasons causing the high rate of child labor domestically and especially in the agricultural sector is the incomplete labor market. Jacoby \& Skoufias (1997) shows that shocks, both collective and idiosyncratic, cause the growth of the labor market. Meanwhile, when faced with crop failure in Tanzania, households deliberately use child labor in consumption smoothing (Beegle et al., 2006). A crop failure in Tanzania has also affected the rise in working hours for boys in the agricultural sector (Bandara et al., 2015). Grimm (2011) described that a drought would allow parents to smooth the consumption by dismissing and encouraging school children to work.

Data and information about natural disaster damage impact on child labor is relatively scarce in Indonesia. It is interesting to know if the hypothesis that the child labor engagement in a part of household buffer shock is closely related to the low capacity of households, both in formal and informal institutions, to survive from various shocks in Indonesia is valid. This research tries to fill the gap in the lack of data and information problem by discovering the impact of disaster damage on the number of child participation in the labor market. Furthermore, this article attempts to deeply analyze if there are differences in the results of child labor between rural or urban location. We specify this research on children with age 5-14 using data in 2014. The data are taken from Indonesian Family Survey 5 th wave in 13 provinces in Indonesia.

\section{Methodology}

\subsection{Data and Approach}

This research use cross-section data based from the fifth wave Indonesian Family Life Survey (IFLS) that was conducted on 2014. IFLS 5th wave was realized by a collaborative work of RAND and Survey Meter. The Indonesia Family Life Survey collects the sample of households that represent about $83 \%$ of the population that living in 13 provinces of Indonesia. The provinces are North Sumatra, West Sumatra, South Sumatra, Lampung, DKI Jakarta, West Java, Central Java, DI Yogyakarta, East Java, Bali, West Nusa Tenggara, South Kalimantan and South Sulawesi. This survey collects data on individuals, families, households and their living communities where they have used health and education facilities. This study observed 10,083 children age between 5 and 14 years old and 7,226 households.

This research attempts to investigate two main issues. Firstly, what is the impact of natural disaster damage on the number of child participation in the labor market. This study uses two approaches in measuring disaster that is disaster dummy and disaster level dummy. Secondly, does the different location 
between rural or urban will also show the different results on impact of disaster on child labor, and then to determine the number of child labor, this study using the children and household characteristics as explanatory variables. To solve the two main issues, the empirical model is written:

$$
Y_{i}=\beta_{0}+\beta_{1} \text { disaster }_{h}+\beta_{n} W_{i h}+\beta_{n} Z_{i h}+\varepsilon_{i h}
$$

where: subscripts index individuals $(i)$, households $(h) ; Y$ is dummy variable for child labor rate/the amount of time spent for working; disaster is measure of disaster dummy variable/disaster level dummy (severe, less severe, and no disaster); and $W$ indicates a control set based on children's characteristics, and $Z$ indicates a control set based on household characteristics.

In the beginning of this research, we use the Logit Model, since the dependent variable is child labor dummy. In the next phase of the analysis, we use the Tobit Model, using children's total working hours. These two methods are commonly used in child labor research. Finally, we utilize Least Absolute Shrinkage and Selection Operator (LASSO) method as robustness check to clarify the result using Logit and Tobit method. For the estimation, we using three different samples: (1) using the full sample, it consists of 10,083 observations; (2) using the rural sample, it consists of 4,193 observations; and (3) using an urban sample which consists of 5,890 observations.

In this paper, we use Logit model to estimate child labor dummy, which is the proper regression analysis which regenerate an equation when the dependent variable is categorical. According to regression analyses function, the logistic regression is used to predict the probability of an event that may happen. Logistic regression is used to find the differences in characteristic between two categories and to understand the factors that affect the one dependent binary variable from one or more nominal, ordinal, interval or ratio-level independent variables.

Moreover, we also use the Tobit model to estimate the child labor working hour. Wooldridge (2002, ch. 6) stated Tobit method, known as a censored regression model, is a regression method that measuring linear relationships between variables when there is either left or right-censoring in the dependent variable. In some studies, the researchers are faced with observations that have an upper or a lower limit. Also, for considerable amount of observations, the variable takes the threshold value. If the absolute values out of the limit are irrelevant and also the probability of falling above or below the limit is the only relevant factor, then a logistic regression will be consistent. On the other hand, when only the absolute values take bare importance, then multiple regressions will be consistent. However, when faced with such data, both procedures will be biased. This form of bias is called the truncation bias or the censored data bias. This model tries to overcome the problems of dependent variable if dependent variable constrained and clustering of observations.

For the robustness check, we propose a double-selection estimator based on the Least Absolute Shrinkage and Selection Operator (LASSO) regression. Given that many variables correlate with dependent and independent variables, this 
approach allows covariates to be selected and included in an empirical model. It avoids under or over the selection of covariates. Frank \& Friedman (1993) and Tibshirani (1996) argue in LASSO; the coefficients choose to minimize the total squared residue plus a penalty term that penalizes model size by the number of absolute factored values. Therefore, the expected LASSO result is consistent with the logit and tobit model.

\subsection{Dependent Variables}

The purpose of this study is to analyze the impacts of disaster damage on child labor. Child labor in this research represent as paid and unpaid child labor, it means every children age between 5 and 14 years old who involved in economics activities and household activities such as helping their parents while they were worked. There are two measurements of child labor which will be the primary focus of this research. First, the dependent variable is Dummy Child Labor (DW) which is the dummy variables of child labor. It will be 1 if the children become a worker, and 0 if otherwise. Kruger (2007) in her research to investigate the effect of coffee industry on the rate of working and school children in rural Brazil used the dummy variable of child labor as the dependent variable. Moreover, Kambhampati \& Rajan (2006) also used dummy variable of child labor in their research in India. Furthermore, the second dependent variable is Children's Total Working Hour (TTW) which is the summation of total working hours in a week, and range of child total working hour is between 0-60 hour/week. Dumas (2007) used children working hour as child labor proxy in his research in Burkina Faso.

\subsection{Main Variables}

To achieve the objectives of this study, we use two primary variables in the model as a proxy of natural disaster, in which definition of natural disaster such as: flood, earthquake, etc. First, the main variable is Disaster Dummy (DISD) which is the dummy variables of natural disaster. It will be 1 if household experienced disaster, and 0 if otherwise. And the second main variable is Disaster Level Dummy (DISL) which is the dummy variables of natural disaster damage level. This research classified disaster level using condition of house damage in household which experienced natural disaster. It will be 0 if household never experienced disaster, 1 if household experienced less severe disaster, and 2 if household experienced severe disaster. Households are often faced with various problems related to the high risk that causes low investment in human capital, such as the economic crisis, death of head or family member, illness, failure of harvest or loss of income caused by natural phenomena due to weather, insect attacks and so on (Maccini \& Yang, 2009). This phenomenon indirectly has implications for the high volatility of income so that it has consequences for using child labor as a buffer for households. Turning their child's school days into a working days as a household buffer shock is one of the last strategies or mechanisms to perform consumption smoothing mostly in developing countries, especially rural areas (Beegle et al., 2006). 


\subsection{Control Variables}

The child labor variable is explained as the characteristics of the children themselves as a person, as well as the internal condition of the families where they belong (De Silva \& Sumarto, 2014; Del Carpio et al., 2016; Gee, 2010; Miller \& Tsoka, 2012; Suryahadi et al., 2005). Regarding the previous studies results, the characteristics that meant to are those children personally as well as those belonging household. These additional control variables are the factors that determine the household and these factors may also explain the crucial effect of disaster on child labor creation. Then, the additional covariates in the model would help improve the precision of the estimates of the causal effect of interest. The children characteristic used in the model are children sex and children age. Children Sex (CSEX) is the dummy variable for children gender. The value will be 1 if the children gender is male, and 0 if the children sex is female. Children Age (CAGE) is the children characteristic that represent the age of children. The value will be a range between 5 and 14 years old. It is expected that the child labor will increase as children get older and decrease when they reach some age point.

We use ten household characteristics in the model. First, the household characteristics variable is Household Total Asset per capita (HTA) which is the log value of total asset divided by household size. Dumas (2007) mentioned that family farm that owns their own farm asset would not hire the non-household worker and they will use their own children as labor to avoid higher income loss. In the "wealth paradox" hypothesis, the greater household wealth will increase the child labor. On the other hand, Basu \& Van (1998) mentioned that in "luxury axiom" theory, child labor would decrease when family wealth increase. Second, Household Head Gender (HHGE) is the dummy variable for household head sex. It will be 1 if the household head gender is male and 0 if the household gender is female. Bhalotra \& Heady (2003) mentioned that household head female had higher probability to send their children to work. Third, Household Head Age (HAGE) is the household head variables that represent the value of household age. Grootaert (1998) investigated child labor in Cote d'Ivoire and found that the older the age of household head, the more likely children are not working. Fourth, Household Farmer (HFARM) is a dummy variable for parent's job. The value would be 1 if the parents worked as the farmer, and 0 if otherwise. Zepeda \& Kim (2006) mentioned that family farms in Wisconsin think that their children as their asset that can help them to work on their farm land. It means that there is a strong correlation between the family farm and child labor. Moreover, the farm family also believed working would increase the children's skill for better future. Fifth, Household Borrowing Money (HBOR) is the dummy variable for household borrowing the money. It would value 1 if any member of household borrowed money and it will equal 0 if the household did not borrow money in the last 12 months. It expected that if household borrows the money, it will be the triggers for household in forcing child to work. The sixth variable is Household Number of Children $(\mathrm{HNCH})$ which is the total number of children in the household. Kruger (2007) found that household with the bigger number of children had a 
positive correlation with child labor. The large family will not have sufficient capital to send children to school and will involve them in the farm land to work. Moreover, this paper also uses Household Number of Adult (HNAD), which is the total number of a household member with age more than 15 years old. A higher number of an adult in the family might reduce the probability of child labor because of the source of income from the adult increase. Next household characteristic is Household Parents Both Alive (HPBA), which is the dummy variable for parents that both are alive. It will value 1 if both parents are alive and it will value 0 if only father or mother is alive. We expected that if a family with both parents alive would have a lower probability to force their children to become a worker. Furthermore, we include Household Parents Only Mother Alive (HMAL) as household characteristics. Household Parents Only Mother Alive (HMAL) is the dummy variables for parents that the only mother is alive. It will value 1 if the only mother is alive and it will value 0 if the only father or both parents are alive. We expected that single parent with the only mother could increase the probability of child labor because income from working child will help the household to overcome income problem. The last household characteristic variable is Household Location (HRURAL), which is the dummy location whether children live in rural or urban. It will value 1 if the children live in rural area, and 0 otherwise. Kruger (2007) found that child labor significantly correlated with rural areas.

\section{Result and Analysis}

Table 1 represent summary of statistics of survey data used in this study illustrates details of Child Labor data in Indonesia. It can be seen that 30.1 percent of total samples is child labor. Comparing between rural area and urban area, the proportion child labor is higher in rural area. By location, 34.7 percent of children sample living in rural area as child labor, and it is bigger than child labor percentage who lives in urban area which is only 26.8 percent.

Table 1 also described the average of working hour in full sample, rural and urban area. The average of working hour in full sample is 2 hours per week, while in the rural area, the average working hours increase to 2.5 hours per week. Furthermore, the working hour is only 1.7 hours a week in the urban area.

In the process of analysing the natural disaster damage impact on child labor, first we used dummy of child work as a dependent variable, which will equal to 1 if child is working, and 0 if otherwise. Furthermore, for main independent variables we use two variables to proxy damage of natural disaster.

The first variables are dummy of disaster which will equal to 1 if household experienced disaster; and 0 if otherwise, and also disaster level which will equal 0 if household never experienced disaster, 1 if household experienced less severe disaster, and 2 if household experienced severe disaster. Using logit model, table 2 shows the impact of disaster damage on child labor. The result describes that disaster damage has a significantly positive impact for household decision on 
Table 1: Summary Statistics

\begin{tabular}{|c|c|c|c|c|c|c|}
\hline & \multicolumn{2}{|c|}{ Full Sample } & \multicolumn{2}{|c|}{ Urban } & \multicolumn{2}{|c|}{ Rural } \\
\hline & Mean & $\begin{array}{c}\text { Std. } \\
\text { Deviation }\end{array}$ & Mean & $\begin{array}{c}\text { Std. } \\
\text { Deviation }\end{array}$ & Mean & $\begin{array}{c}\text { Std. } \\
\text { Deviation }\end{array}$ \\
\hline Dummy of child work (DW) & 0.301 & 0.459 & 0.268 & 0.443 & 0.347 & 0.476 \\
\hline Child work hours (TTW) & 2.067 & 6.246 & 1.703 & 5.749 & 2.578 & 6.852 \\
\hline Dummy of disaster (DISD) & 0.217 & 0.412 & 0.224 & 0.417 & 0.207 & 0.405 \\
\hline \multicolumn{7}{|l|}{ Disaster level (DISL) } \\
\hline No disaster & 0.783 & 0.412 & 0.776 & 0.417 & 0.793 & 0.405 \\
\hline Less severe disaster & 0.188 & 0.390 & 0.194 & 0.395 & 0.179 & 0.384 \\
\hline Severe disaster & 0.029 & 0.169 & 0.030 & 0.171 & 0.028 & 0.164 \\
\hline Household asset per capita (HTA) & 16.656 & 1.877 & 16.648 & 1.977 & 16.666 & 1.727 \\
\hline Dummy of child's gender (CSEX) & 0.513 & 0.500 & 0.520 & 0.500 & 0.502 & 0.500 \\
\hline Child's age (CAGE) & 9.354 & 2.862 & 9.334 & 2.872 & 9.383 & 2.846 \\
\hline $\begin{array}{l}\text { Dummy of household head's } \\
\text { gender (HHGE) }\end{array}$ & 0.874 & 0.331 & 0.872 & 0.335 & 0.879 & 0.327 \\
\hline Household head's age (HAGE) & 43.299 & 10.087 & 43.388 & 10.659 & 43.174 & 11.012 \\
\hline Dummy of farmer (HFARM) & 0.0916 & 0.289 & 0.040 & 0.196 & 0.164 & 0.370 \\
\hline Dummy of borrower (HBOR) & 0.330 & 0.470 & 0.358 & 0.479 & 0.291 & 0.454 \\
\hline $\begin{array}{l}\text { Number of children in the } \\
\text { household }(\mathrm{HNCH})\end{array}$ & 2.256 & 1.176 & 2.313 & 1.176 & 2.175 & 1.171 \\
\hline $\begin{array}{l}\text { Number of adults }(15+) \text { in the } \\
\text { household (HNAD) }\end{array}$ & 1.999 & 0.549 & 1.998 & 0.551 & 2.001 & 0.545 \\
\hline Dummy of both parents (HPBA) & 0.909 & 0.288 & 0.903 & 0.296 & 0.917 & 0.277 \\
\hline Dummy of only mother (HMAL) & 0.063 & 0.242 & 0.068 & 0.251 & 0.055 & 0.229 \\
\hline Dummy of rural area (HRURAL) & 0.416 & 0.493 & - & - & - & - \\
\hline No. Observations & 10,083 & & 5,89 & & 4,193 & \\
\hline
\end{tabular}

Source: Authors' calculation

child labor enforcement as a buffer or consumption smoothing because of loss of income. Urban area also has the same result, but in the rural area the result is not significant. Meanwhile, when we using disaster damage level as our main independent variables, the result shows that household which experienced severe disaster has a significantly positive impact for household decision on child labor enforcement both using the full and urban samples. Whilst, not that significant when we used rural area samples.

Next, we used children working hours as proxy of child labor. Dumas (2007) used children working hour as child labor proxy in his research in Burkina Faso. This variable recording the calculation of the total working hours spent in the previous week, and ranges from 0 to 60 hours. Utilizing tobit model, Table 3 shows that natural disaster damage also has a significantly positive impact on increasing child working hours when we used full and urban area samples. It's means that when disaster happen, household tend to exploit their children to work harder than before to overcome their problems. Moreover, household which experienced less severe and severe disaster both have a positive and significant impact for their decision to send their children to work both using the full and urban samples, but not that significant when we used rural area samples.

This finding is verifying the several previous studies that analysing relation- 
Table 2: Logit Regression Results

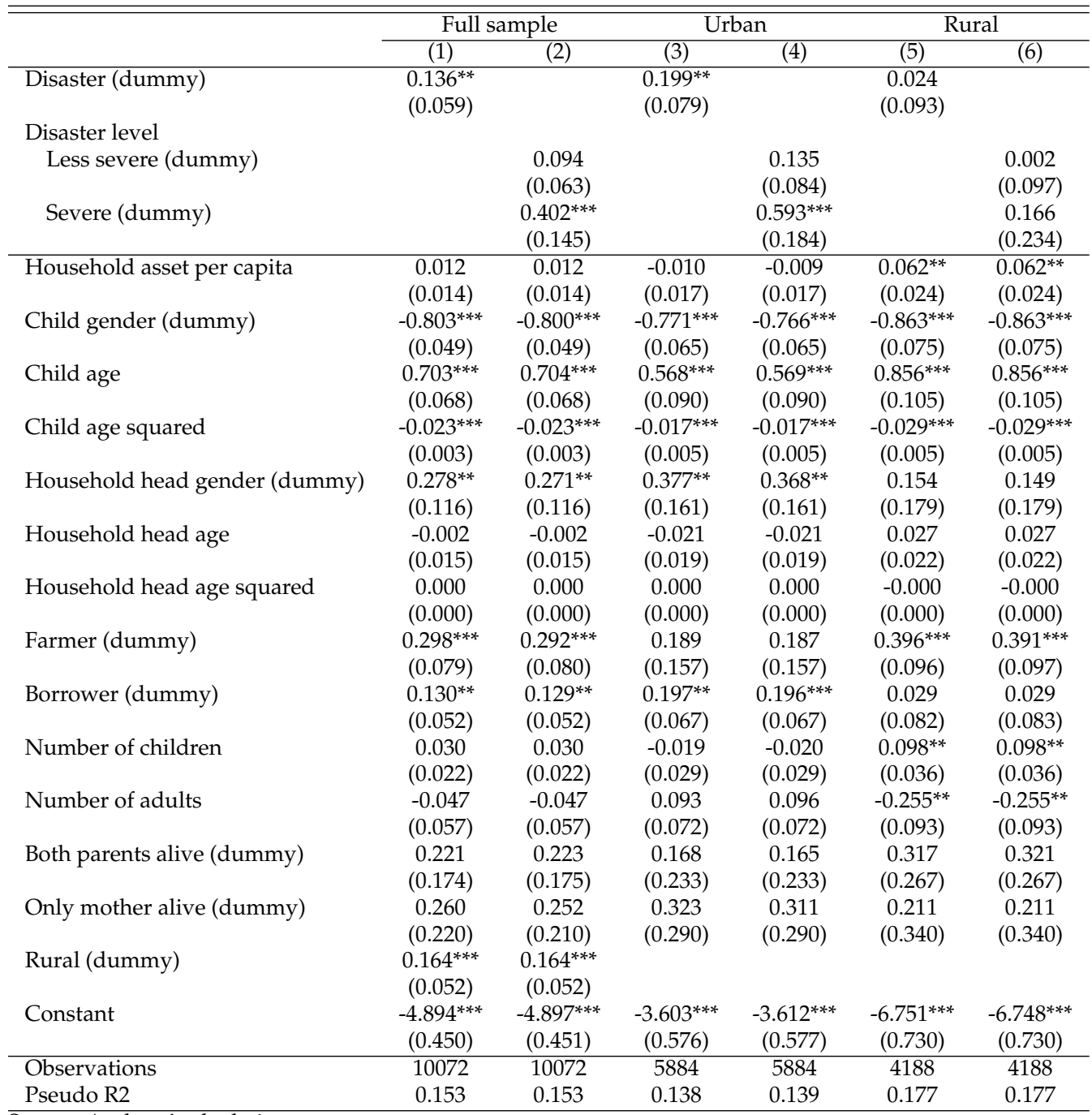

Source: Authors' calculation

Notes: (1) All models include province dummies.

(2) ${ }^{* * *}, * *$, and $*$ indicate the statistical significance at the $1 \%, 5 \%$, and $10 \%$ levels, respectively.

(3) Robust standard errors are in parentheses.

ship between Income shock and Child Labor. Household decision to force their children to become a labor as a buffer shock is one of the last strategies or mechanisms which a lot of evidence is found in developing countries to consumption smoothing (Beegle et al., 2006). Skoufias \& Parker (2002) states that the child labor phenomenon is closely related to the poor capacity of households to survive from 
Table 3: Tobit Regression Results

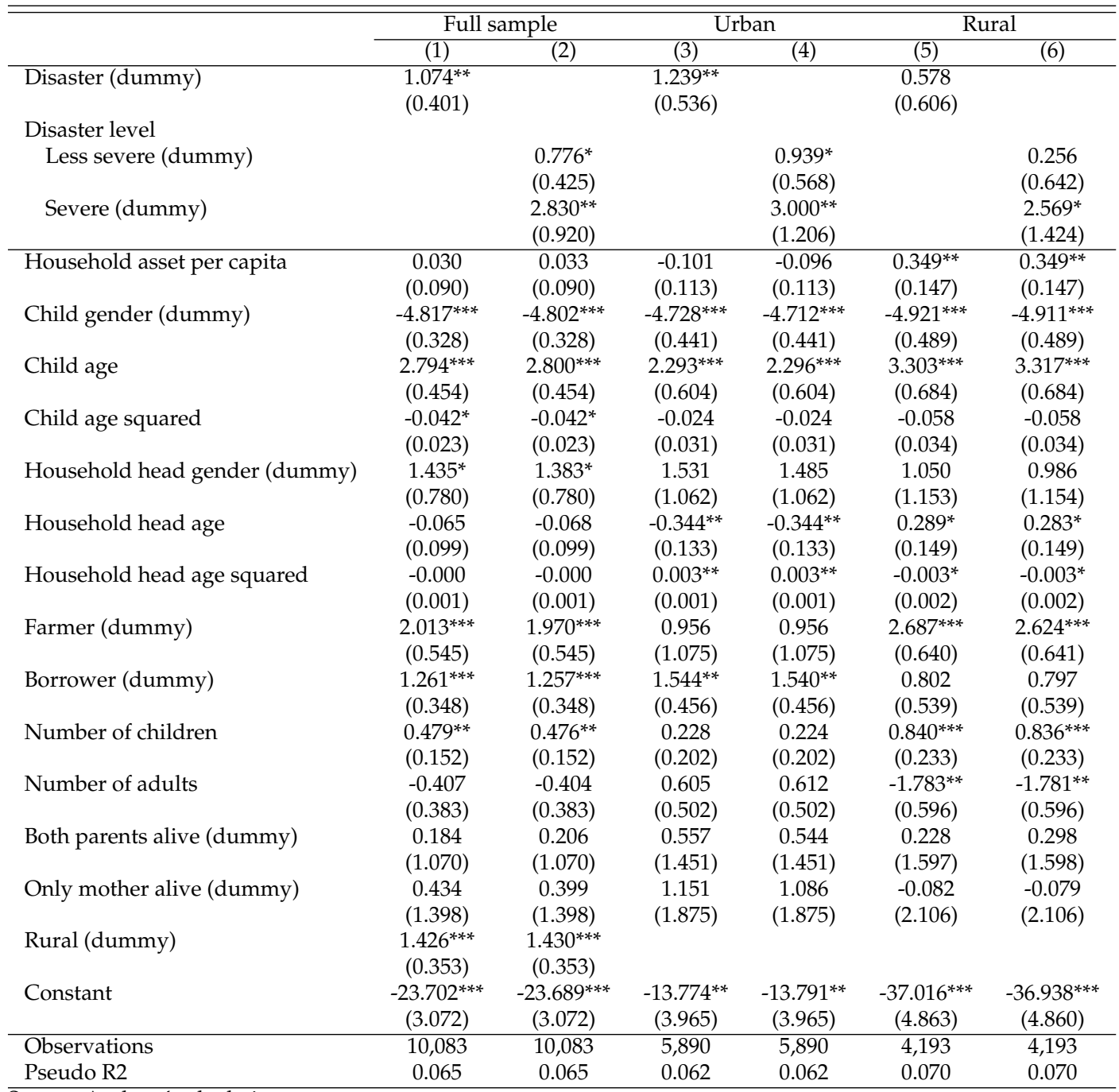

Source: Authors' calculation

Notes: (1) All models include province dummies.

(2) ${ }^{* * *}, * *$, and $*$ indicate the statistical significance at the $1 \%, 5 \%$, and $10 \%$ levels, respectively.

(3) Robust standard errors are in parentheses.

various shocks. The results also determine that increasing child labor hours is not the only response to a shock, but also educational enrolment struggling.

The result in Table 2 and 3 also describes the correlation between variable of child labor and the characteristics of children and household. The relationship between child labor and children gender is significantly negative in all sample. 
It's means that girls have higher probability with child labor. Parents prefer to use their daughters to work as child labor compares to their sons. Besides that, the correlation between child labor and children age create inverted U-shaped. It implies that the older children have a higher probability of being send as child labor, and until some age it will decrease. Household asset per capita has a positive relationship with child labor in full and rural area samples, but only significant in rural area. The positive correlation is inconsistent with "luxury axiom" hypothesis published by Basu \& Van (1998), which was stated that child labor would decrease when family wealth increase. In contrary, urban area result is consistent with "luxury axiom" hypothesis but not significant. The result also shows that household head gender has a positive correlation with child labor on all sample. It implies that a male household head has higher probability to send their children to work than female. Parent job as a farmer also have a positive and significant impact on child labor using full and rural area samples. These finding confirms the argument that children is an 'asset' in household farm, which also found from previous empirical studies, such as Light et al. (1985), Saupe \& Bentley (1994), Kim \& Zepeda (2004), and Zepeda \& Kim (2006). Moreover, the relation between child labor and household borrowing is significantly positive in full and urban area sample. It implies that parent who lives in the urban will force their children to become a labor to get additional revenue to pay their debt. Furthermore, the quantity of adult members in household has a significantly negative correlation with the rate of child labor in the rural area. It implies that in the rural area, the higher number of adults in the family will decrease the probability of household to force their children to work.

One crucial problem is that model selection mistakes may occur so that the empirical validity relies on a perfect model selection (Belloni et al., 2014). The omission of some independent variables that have non-zero effects may cause model selection mistakes by generally contaminating estimation and inference results. Given the fact that model selection mistakes seem inevitable, recent studies focus on a small set of independent variables of interest, leaving the model selection to be done only over "nuisance" parts of the problem.

Belloni et al. (2014) propose a double-selection approach, based on the Least Absolute Shrinkage and Selection Operator (LASSO) regression. In LASSO, the coefficients choose to minimize the sum of the squared residuals plus a penalty term that penalizes the size of the model through the number of absolute values of the factors (Frank \& Friedman, 1993; Tibshirani, 1996). The first step is to apply a lasso regression to identify covariates that predict the dependent variable, and the second step is to use a lasso regression to identify covariates that predict the independent focal variable. With the results in the first step, the second step also determines the union of the selected covariates from the first and second steps.

The final step is to regress the dependent variable on the covariate of interest and the association of the selected covariates. This study estimates the following model:

$$
y_{i}=\alpha+x_{h} \beta+\hat{z}_{i h} \gamma+\varepsilon_{i h}
$$


where subscripts index individuals $(i)$, households $(h) ; Y$ is child labor dummy variable/child working hours; $X$ is measure of disaster dummy variable/disaster level dummy (severe, less severe, and no disaster); $\hat{z}_{i h}$ is the union of the selected covariates; and $\varepsilon_{i n}$ is the error term. The estimate of $\beta$ is the coefficient of the variable of interest in this study. Therefore, the expected LASSO result is consistent with the logit and tobit model.

Table 4: Double-selection Model Results

\begin{tabular}{|c|c|c|c|c|c|c|c|}
\hline \multirow[t]{2}{*}{ Sample } & \multirow{2}{*}{$\begin{array}{l}\text { Dependent } \\
\text { variable }\end{array}$} & \multirow{2}{*}{$\begin{array}{l}\text { Disaster } \\
\text { (dummy) }\end{array}$} & \multicolumn{2}{|c|}{ Disaster level } & \multirow{2}{*}{$\begin{array}{l}\text { No. of } \\
\text { obs. }\end{array}$} & \multirow{2}{*}{$\begin{array}{l}\text { No. of } \\
\text { controls }\end{array}$} & \multirow{2}{*}{$\begin{array}{l}\text { No. of selected } \\
\text { controls }\end{array}$} \\
\hline & & & $\begin{array}{l}\text { Less severe } \\
\text { (dummy) }\end{array}$ & $\begin{array}{l}\text { Severe } \\
\text { (dummy) }\end{array}$ & & & \\
\hline \multirow[t]{6}{*}{ Full } & $\begin{array}{l}\text { Child work } \\
\text { dummy }\end{array}$ & $1.146^{* *}$ & & & 10083 & 43 & 16 \\
\hline & & $(0.067)$ & & & & & \\
\hline & & & $\begin{array}{l}1.100 \\
(0.069)\end{array}$ & $\begin{array}{l}1.550^{* * *} \\
(0.219)\end{array}$ & 10083 & 43 & 18 \\
\hline & Child work & $0.294^{* *}$ & & & 10083 & 43 & 17 \\
\hline & & $(0.148)$ & & & & & \\
\hline & & & $\begin{array}{l}0.260^{*} \\
(0.153)\end{array}$ & $\begin{array}{l}0.587 \\
(0.419)\end{array}$ & 10083 & 43 & 20 \\
\hline \multirow[t]{6}{*}{ Urban } & $\begin{array}{l}\text { Child work } \\
\text { dummy }\end{array}$ & $1.240^{* *}$ & & & 5890 & 43 & 9 \\
\hline & & $(0.096)$ & & & & & \\
\hline & & & $\begin{array}{l}1.163^{*} \\
(0.096)\end{array}$ & $\begin{array}{l}1.864^{* * *} \\
(0.334)\end{array}$ & 5890 & 43 & 12 \\
\hline & $\begin{array}{l}\text { Child work } \\
\text { hours }\end{array}$ & 0.175 & & & 5890 & 43 & 9 \\
\hline & & $(0.172)$ & & & & & \\
\hline & & & $\begin{array}{l}0.167 \\
(0.182)\end{array}$ & $\begin{array}{l}0.301 \\
(0.407)\end{array}$ & 5890 & 43 & 13 \\
\hline \multirow[t]{6}{*}{ Rural } & $\begin{array}{l}\text { Child work } \\
\text { dummy }\end{array}$ & 1.053 & & & 4193 & 43 & 11 \\
\hline & & (0.095) & & & & & \\
\hline & & & $\begin{array}{l}0.996 \\
(0.096)\end{array}$ & $\begin{array}{l}1.116 \\
(0.266)\end{array}$ & 4193 & 43 & 13 \\
\hline & $\begin{array}{l}\text { Child work } \\
\text { hours }\end{array}$ & 0.347 & & & 4193 & 43 & 10 \\
\hline & & $(0.264)$ & & & & & \\
\hline & & & $\begin{array}{l}0.256 \\
(0.268)\end{array}$ & $\begin{array}{l}1.154 \\
(0.829)\end{array}$ & 4193 & 43 & 13 \\
\hline
\end{tabular}

Source: Authors' calculation

Notes: (1) The disaster (dummy) column shows the odds ratio.

(2) ${ }^{* * *}, * *$, and * indicate the statistical significance at the $1 \%, 5 \%$, and $10 \%$ levels, respectively.

(3) Robust standard errors are in parentheses.

The result in table 4 shows that when we used child work dummy as a proxy of child labor, two main variables that we used as proxy of disaster (disaster dummy and disaster level) have a consistent result compared to logit and tobit model result on all samples. Moreover, when we used child work hours as a 
proxy of child labor, two main variables that we used as proxy of disaster (disaster dummy and disaster level) also have a positive relationship and consistent result too.

\section{Conclusion}

This research has analyzed the effect of natural disaster damage on child labor using cross section data from the fifth wave Indonesia Family Life Survey (IFLS). Our results show that natural disaster damage have a positive relationship with child labor in all sample. It means that household which experienced natural disaster have more probability to let their children become a worker as a buffer to overcome their loss income. However, this relationship is more significant in the urban area. Moreover, there are a significant difference between urban area and rural area among impact of others factor on child labor. The result prove that the level of income per capita in household has a significantly positive impact on the rate of child labor in rural area, while in urban area it has a negative correlation. The positive relationship in rural area is contradicted with "luxury axiom" hypothesis which assumes that the number of child labor would go down when household wealth getting better. Furthermore, number of adults (15+) in the family also have a difference effect on child labor between urban and rural area. In rural area, the greater number of adults on the family is more likely decrease the possibility to force their children become a worker, whilst otherwise in urban area.

The results of this study imply that damage of natural disaster have positive and significant effect on household decision to force their children become a worker, especially in urban area. The phenomenon of increasing child labor is viewed as a policy problem, so it is very important to create a policies that insure households capacity in cope with such disaster shocks that will lead to reduce the level of child labor. The Government through the Ministry of Social Affairs must further improve supervision of the implementation of the Family Hope Program (Program Keluarga Harapan), a conditional cash assistance program launched in 2007 as part of a poverty alleviation initiative that requires cash grant recipients to continue sending their children to primary education, and all children school age (6 to 15 years) must maintain an attendance rate of at least 85 percent. Furthermore, the government must build public awareness of the importance of investing human resources in their children rather than merely apprehending children as assets. In addition, the government must also ease the burden on parents by lowering school fees or freeing all costs, so that will stimulate more chance for children to go to school rather than become a labor.

\section{References}

[1] Bandara, A., Dehejia, R., \& Lavie-Rouse, S. (2015). The impact of income and nonincome shocks on child labor: Evidence from a panel survey of Tanzania. World 
Development, 67, 218-237. doi: https://doi.org/10.1016/j.worlddev.2014.10.019.

[2] Basu, K., \& Van, P. H. (1998). The economics of child labor. American Economic Review, 88(3), 412-427. https://www.jstor.org/stable/116842.

[3] Beegle, K., Dehejia, R. H., \& Gatti, R. (2006). Child labor and agricultural shocks. Journal of Development Economics, 81(1), 80-96. doi: https://doi.org/10.1016/j.jdeveco.2005.05.003.

[4] Belloni, A., Chernozhukov, V., \& Hansen, C. (2014). Inference on treatment effects after selection among high-dimensional controls. The Review of Economic Studies, 81(2), 608-650. doi: https://doi.org/10.1093/restud/rdt044.

[5] Bhalotra, S., \& Heady, C. (2003). Child farm labor: The wealth paradox. The World Bank Economic Review, 17(2), 197-227. doi: https:/ /doi.org/10.1093/wber/lhg017.

[6] De Silva, I., \& Sumarto, S. (2014). Does economic growth really benefit the poor? Income distribution dynamics and pro-poor growth in Indonesia. Bulletin of Indonesian Economic Studies, 50(2), 227-242. doi: https://doi.org/10.1080/00074918.2014.938405.

[7] Del Carpio, X. V., Loayza, N. V., \& Wada, T. (2016). The impact of conditional cash transfers on the amount and type of child labor. World Development, 80, 33-47. doi: https://doi.org/10.1016/j.worlddev.2015.11.013.

[8] Dumas, C. (2007). Why do parents make their children work? A test of the poverty hypothesis in rural areas of Burkina Faso. Oxford Economic Papers, 59(2), 301-329. doi: https://doi.org/10.1093/oep/gpl031.

[9] Edmonds, E. V. (2006). Understanding sibling differences in child labor. Journal of Population Economics, 19(4), 795-821. doi: https:/ / doi.org/10.1007/s00148-005-0013-3.

[10] Fitzsimons, E. (2007). The effects of risk on education in Indonesia. Economic Development and Cultural Change, 56(1), 1-25. doi: https://doi.org/10.1086/520560.

[11] Frank, L. E., \& Friedman, J. H. (1993). A statistical view of some chemometrics regression tools. Technometrics, 35(2), 109-135. doi: https:/ / doi.org/10.1080/00401706.1993.10485033.

[12] Gee, K. A. (2010). Reducing child labour through conditional cash transfers: Evidence from nicaragua's red de protección social. Development Policy Review, 28(6), 711-732. doi: https://doi.org/10.1111/j.1467-7679.2010.00506.x.

[13] Grimm, M. (2011). Does household income matter for children's schooling? Evidence for rural Sub-Saharan Africa. Economics of Education Review, 30(4), 740-754. doi: https://doi.org/10.1016/j.econedurev.2011.03.002.

[14] Grootaert, C. (1998). Child labor in Cote d'Ivoire: incidence and determinants. Policy Research Working Papers, 1905. The World Bank. doi: https://doi.org/10.1596/18139450-1905.

[15] Jacoby, H. G., \& Skoufias, E. (1997). Risk, financial markets, and human capital in a developing country. The Review of Economic Studies, 64(3), 311-335. doi: https://doi.org/10.2307/2971716.

[16] Kambhampati, U. S., \& Rajan, R. (2006). Economic growth: A panacea for child labor?. World Development, 34(3), 426-445. doi: https://doi.org/10.1016/j.worlddev.2005.08.010.

[17] Kim, J., \& Zepeda, L. (2004). When the work is never done: Time allocation in US family farm households. Feminist Economics, 10(1), 115-139. doi: https://doi.org/10.1080/1354570042000198254.

[18] Kruger, D. I. (2007). Coffee production effects on child labor and schooling in rural Brazil. Journal of Development Economics, 82(2), 448-463. doi: https://doi.org/10.1016/j.jdeveco.2006.04.003. 
[19] Light, H. K., Hertsgaard, D., \& Martin, R. E. (1985). Farm children's work in the family. Adolescence, 20(78), 425-432.

[20] Maccini, S., \& Yang, D. (2009). Under the weather: Health, schooling, and economic consequences of early-life rainfall. American Economic Review, 99(3), 1006-1026. doi: 10.1257/aer.99.3.1006.

[21] Miller, C., \& Tsoka, M. (2012). Cash transfers and children's education and labour among Malawi's poor. Development Policy Review, 30(4), 499-522. doi: https://doi.org/10.1111/j.1467-7679.2012.00586.x.

[22] Ray, R. (2000). Analysis of child labour in Peru and Pakistan: A comparative study. Journal of Population Economics, 13(1), 3-19. doi: https://doi.org/10.1007/s001480050119.

[23] Saupe, W. E., \& Bentley, S. (1994). Introduction to the survey. In B. Barham, S. Bentley, F. Buttel, J. Eisenhauer, Douglas B. Jackson-Smith, \& W. Saupe, Status of Wisconsin farming, special edition: The 1993 ATFFI family farm survey. Department of Agricultural Economics and the Agricultural Technology and Family Farm Institute, University of Wisconsin-Madison.

[24] Skoufias, E., \& Parker, S. W. (2002). Labor market shocks and their impacts on work and schooling: evidence from urban Mexico. FCND Discussion Paper, 129. Food Consumption and Nutrition Division - International Food Policy Research Institute. https://ebrary.ifpri.org/digital/collection/p15738coll2/id/47974.

[25] Suryahadi, A., Priyambada, A., \& Sumarto, S. (2005). Poverty, school and work: Children during the economic crisis in Indonesia. Development and Change, 36(2), 351-373. doi: https://doi.org/10.1111/j.0012-155X.2005.00414.x.

[26] Tang, C., Zhao, L., \& Zhao, Z. (2018). Child labor in China. China Economic Review, 51, 149-166. doi: https://doi.org/10.1016/j.chieco.2016.05.006.

[27] Tibshirani, R. (1996). Regression shrinkage and selection via the lasso. Journal of the Royal Statistical Society: Series B (Methodological), 58(1), 267-288. doi: https://doi.org/10.1111/j.2517-6161.1996.tb02080.x.

[28] Wooldridge, J. M. (2002). Econometric analysis of cross section and panel data. MIT Press.

[29] Zepeda, L., \& Kim, J. (2006). Farm parents' views on their children's labor on family farms: A focus group study of Wisconsin dairy farmers. Agriculture and Human Values, 23(1), 109-121. doi: https:/ / doi.org/10.1007/s10460-004-5873-8. 